\title{
Sustainable Intensification of Rice-Based Systems with Potato in Eastern Indo-Gangetic Plains
}

\author{
Marcel Gatto ${ }^{1}$ (D) - Athanasios Petsakos ${ }^{2} \cdot$ Guy Hareau $^{2}$
}

Published online: 31 January 2020

(C) The Author(s) 2020

\begin{abstract}
In many parts of Asia food security and poverty remain issues even though arable land is available to produce nutritious food. Sustainable intensification of agricultural systems has been proposed to produce more outputs on same land area whilst minimizing environmental degradation. Tradeoffs, however, are inevitable and evidence thereof is scant. In this study, we analyze effects of sustainable intensification of rice-based systems with potato and focus on the Eastern Indo-Gangetic Plains of India and Bangladesh. A literature review, expert consultation, and an economic surplus exercise are used to address our objective. We find that sustainable intensification has a huge potential and positive welfare effects. Socio-economic tradeoffs, especially for labour, need to be considered and balanced out. Increasing input efficiency for instance by improving farming practices may reduce negative environmental effects.
\end{abstract}

\section{Resumen}

En muchos lugares de Asia la seguridad alimentaria y la pobreza permanecen como temas aun cuando la tierra cultivable esta disponible para producir alimentos nutritivos. Se ha propuesto la intensificación sustentable de los sistemas agrícolas para producir mas en la misma superficie de suelo mientras que se minimice la degradación ambiental. No obstante, las concesiones son inevitables, de aquí que su evidencia es escasa. En este estudio, analizamos los efectos de la intensificación sustentable de sistemas basados en el arroz con papa, con un enfoque en las planicies del oriente Indo-Gangeticas de India y Bangladesh. Para alcanzar nuestro objetivo se uso una revisión de literatura, consulta a expertos, y un ejercicio de superávit económico. Encontramos que la intensificación sustentable tiene un tremendo potencial y efectos positivos en el bienestar. Los intercambios socio-económicos y la especialidad en mano de obra necesitan considerarse y balancearse. Aumentando la eficiencia de los insumos, por ejemplo mediante el mejoramiento de las prácticas de labranza, pueden reducir los efectos ambientales negativos.

Keywords Sustainable intensification $\cdot$ Potato $\cdot$ Asia $\cdot$ Tradeoffs

\section{Introduction}

Asia faces a tremendous food security challenge. Climate change, rapid population growth and the loss of arable land to urbanization exacerbate the problem (Knox et al. 2012; Masters et al. 2013; Wheeler and von Braun 2013; Gerland et al. 2014). Meanwhile, existing arable land is intensified

Marcel Gatto

m.gatto@cgiar.org

1 International Potato Center, Social and Nutrition Sciences Division, Tu Liem, Hanoi, Vietnam

2 International Potato Center, Social and Nutrition Sciences Division, La Molina, Lima, Peru through monocropping and increasing use of pesticides and chemical fertilizers negatively affect the environment and its eco-system services (Liu et al. 2015). Globally, Asia also has the highest concentration of poverty. India and Bangladesh, for instance, jointly are home to some 300 million poor people living on less than US\$ 1,90/day in 2012 (World Bank 2012). In addition, Asian economies, farming systems and diets depend on a few commodities (Garnett et al. 2013) - mainly rice and wheat. This dependency, alongside a lack of income to purchase sufficient and quality food, contributes to high under- and malnutrition rates. Especially women and children under five are affected. India and Bangladesh report among the highest levels of infant and maternal morbidity and mortality (FAO 2015).

Sustainable intensification (SI) has recently gained popularity and attention (Garnett et al. 2013). It acknowledges the 
importance of intensification and diversification of existing agricultural systems, but in a sustainable way. Although various definitions of the concept have been proposed (Godfray and Garnett 2014), a consensus exists about its core: reducing pressure on the environment without compromising on securing future food production (Garnett et al. 2013). In a smallholder context this translates into producing more yields on same area of land and to reduce negative externalities to a minimum. SI offers a strategy to reduce agricultural expansion which comes at considerable environmental costs through the loss of forest land and increasing greenhouse gas emissions (Tilman et al. 2011).

The SI literature has pointed to three major elements: productivity innovations (i.e., improved varieties, improved farming practices, such as integrated pest management), natural resource management innovations (i.e., erosion control), and institutional innovations (i.e., markets and farm inputs) that have overall received relatively little attention (Schut et al. 2016). Given the complexity of the SI concept, there is also a lack of clarity about the set of indicators used to assess the sustainability of an intensified system for specific contexts at household levels. Zurek et al. (2015) provide a SI framework with a focus on higher-level analyses and the intention to provide a tool for policy-makers. In contrast, Smith et al. (2017) provide a detailed framework of sustainability indicators in the context of livestock systems.

In this paper we contribute to the literature by adopting existing SI frameworks and adapt these to a specific case. We focus on the Indo-Gangetic Plains (IGP) of East India and Bangladesh where traditional rice-based cropping systems dominate the agricultural landscape. A fallow period in between the two rice cycles, however, allows farmers to intensify their cropping systems. Whereas various crops, such as pulses or mustard are suitable for intensification, our interest is on potato (Solanum tuberosum). Early-maturing potato varieties which bulk within 75-90 days may be ideal for intensification without incurring major yield penalties, thus contributing to increasing rural incomes and improving diets. Potato is an important crop in our study region and production nearly doubled during the past decade (FAOSTAT 2016).

The SI process inevitably results in social, economic, and environmental tradeoffs. The most obvious one frequently addressed is between producing more food (on same area of land) and minimizing environmental degradation (Smith et al. 2017). Naturally, replacing fallow land with improved potato varieties will boost productivity of the entire agricultural system, but also exacerbate the negative environmental externalities. In contrast, household level social indicators such as labour and gender inclusiveness have received much less attention. Labour availability and farming households' choice to use hired or family labour has not been analyzed in the context of SI. In addition, although gender disaggregated adoption decisions of SI practices have been previously examined
(Ndiritu et al. 2014; Theriault et al. 2017), how additional labour requirements change gender dynamics and equity is not well understood. In sum, literature on context-specific application of SI (i.e., rice-potato-rice cropping systems in Eastern IGP) that focus on the various household-level tradeoffs remains scant.

This study will address two research questions:

(1) What is the potentiality for sustainably intensification of rice-based systems with potato in Eastern IGP?

(2) What are the effects of sustainable intensification on farming outputs and inputs?

Given the limited experimental evidence on the actual agronomic and economic benefits of SI on existing cropping systems, we apply a multimethod approach to address the formulated research questions. Instead of presenting new research results, this paper synthesizes available information from various sources including expert opinions, existing literature, and performs a simple modeling exercise to simulate potential welfare impacts of SI on rice-based systems in Eastern IGP. This synthesis attempts to identify knowledge gaps and to inform future research regarding the data requirements for the integrated impact assessment of SI, thus laying the basis for more detailed analysis of its potential benefits and trade-offs at the agronomic, societal and environmental level.

The paper is organized as follows. We continue section 2 with a presentation of a sustainability indicator framework relevant for our context. Section 3 will provide relevant background information of the study area. We describe material and methods used in section 4 . In section 5, we present the results and, finally, in section 6 we discuss the main findings.

\section{Sustainable Intensification}

\section{Sustainability Indicators Framework}

In a perfect world, SI achieves to produce more outputs in an efficient way (i.e., less inputs) while minimizing environmental damages. In practice, however, this will not always be possible. Competition between different priorities of SI are inevitable and thus decision makers have to consider tradeoffs (Garnett et al. 2013). To do so, it is crucial to gain an understanding of various sustainability indicators and tradeoffs of rice-potato-rice systems. Zurek et al. (2015) and Smith et al. (2017) both provide a list of various sustainability indicators and their respective metrics. The main ones relevant for this research are summarized in Fig. 1.

A priority of SI is to increase farming outputs in terms of productivity and thus incomes. Unless proper economic incentives are achieved/sustained through the improved system, farmers will likely hesitate to intensify their rice-systems with 
Fig. 1 Sustainability indicators framework for intensified cropping systems adapted from Zurek et al. (2015) and Smith et al. (2017)

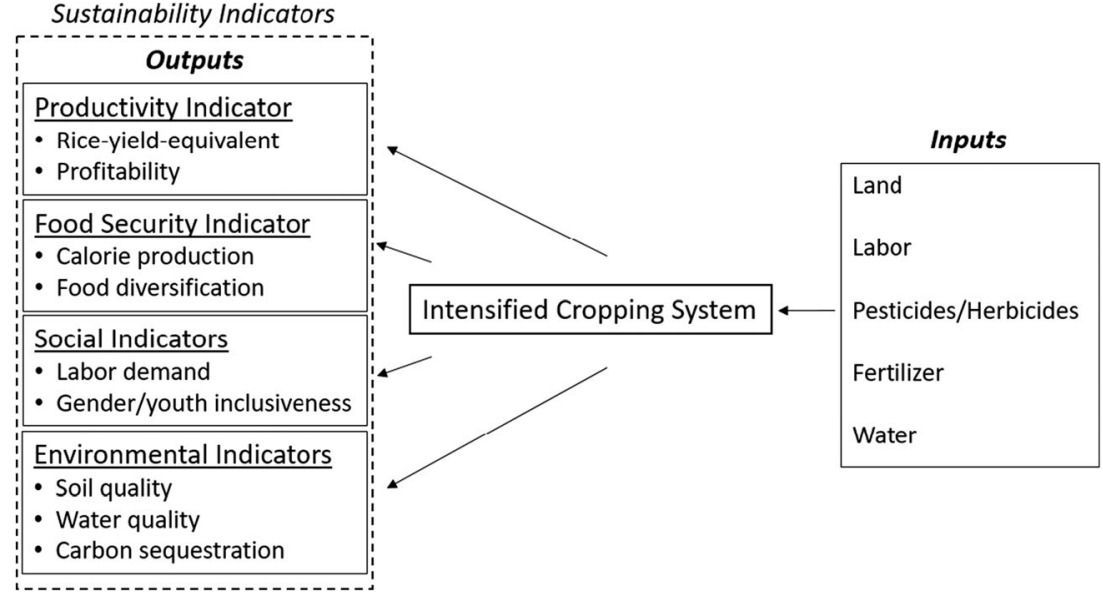

potato. A commonly used productivity measure is the 'RiceYield-Equivalent' (RYE). It compares yields across different cropping systems by converting yield of different crops in the system into rice yield equivalents (Biswas et al. 2006).

Profitability is another productivity indicator. The intensified system intends to generate additional incomes for farming households in rural areas. Farm profitability is usually measured in terms of revenues minus costs. To compare profitability across cropping systems, we apply the Benefit-Cost-Ratio (BCR) which is calculated as production costs over gross returns (Bardhan Roy et al. 2007).

Increases in calorie production to feed a growing population is another priority of SI (Garnett et al. 2013). Although the focus is on producing calories per se, intensification and diversification are also important in terms of combating hidden hunger (i.e., absence of micronutrients in diets). Potatoes are a good source for an improved diet. Compared with rice, potatoes have less calories but are richer in micronutrients such as Vitamin C, iron, or Vitamin B-6.

Sustainability can also be measured in terms of social indicators. For example, the intensification of rice systems requires additional labour days to manage the introduced potato on land which would have been left fallow otherwise. Thus, demand for labour increases which, in principle, leads to more rural employment opportunities and higher incomes. In addition, apart from increasing demand for labour, intensification offers opportunities to boost the involvement of women and youth in agriculture.

Intensification will only be sustainable if the increase in outputs is realized by making more efficient use of the inputs and by minimizing negative environmental effects. These can be manifold, including effects on soil and water quality, and carbon sequestration. The next section briefly discusses some key potential tradeoffs.

\section{Tradeoffs of Sustainable Intensification}

Tradeoffs between outputs and sustainability indicators are inherent to the concept of SI. The extent, however, to which the negative effects on the environment are minimized and the output maximized depends on the efficiency in using the given inputs.

In both traditional and intensified rice-based systems with potato, the input land is held constant. In the first case, the fallow period allows nutrients in the soil and water levels to replenish. In the intensified case, fallow land is transformed into crop area used for agricultural production. Although the fallow period holds important ecological and agricultural functions, from an SI perspective, intensification utilizes land in a more efficient way. In doing so, negative (unintended) environmental implications are inevitable.

For example, more of each of the inputs like pesticides and fertilizers will be required in case of intensification. Although generally increasing input level results in negative implications for soil and water due to runoffs, the intensified system may benefit from fertilizer residues from the additional fertilizer application. Water requirements, on the other hand, will naturally increase in the intensified system. In irrigated systems, this may increase pressure on existing water resources.

The intensified cropping system will require more labour. The farmer can decide to hire labour or use family labour. In the latter case, family members may be readily available which means that the household can make more efficient use of this input. However, the initial fallow period may also be used by family members to engage in other off-farm incomegenerating activities. Depending on the opportunity costs of these activities, family members will continue working onfarm or hire wage labour.

\section{Study Area}

The Eastern Indo-Gangetic Plains comprises the Indian State, West Bengal, and much of Bangladesh. The region is characterized by mainly lowlands with a hot sub-humid climate, a mild winter, and a rainfall of 1000-1800 mm per annum. Due to high rainfall, flooding is a recurrent event (Balasubramanian 
et al. 2012). Usually, late drainage delays planting of subsequent crops and, sometimes, soil moisture stress even prevents planting (Bardhan Roy et al. 2007). More generally, climate change and increasing climate variability at large will have drastic implications for food systems (Aggarwal et al. 2004) along with projected reductions in yields (Kumar et al. 2015).

Rice cultivation dominates in our study region. In Bangladesh and West Bengal, rice is produced on a total of 6.05 and 5.5 million hectares, respectively (Balasubramanian et al. 2012; ICAR 2018). Usually, Kharif, or summer/ rainy rice, is planted in June/July and harvested after 135 days. A few month later, in January/February, during the pre-kharif season, boro (winter) rice is planted and harvested after 120 days (Fig. 2). The period in between these two rice seasons is generally referred to as rabi and offers an opportunity to intensify and diversify agricultural systems. Chickpeas, lentils, mustard, and potatoes are frequently cultivated during the rabi season (Jat et al. 2011). Whereas the rabi season is greatly utilized, abundant agricultural land suitable for intensification is frequently left fallow. In Bangladesh and West Bengal combined suitable land amounts to about 6.2 million (Balasubramanian et al. 2012).

Despite the prevalence of rice cultivation, potatoes are also becoming increasingly important in our study region. According to official statistics, potato production has almost doubled in Bangladesh and India in the last two decades (FAOSTAT 2016), contributing to increasing rural incomes and food security. In our study area, about 870,000 ha are under potato cultivation in 2015, of which almost half is in West Bengal (see Table 1). $79 \%$ of the potato area is cultivated in the South and Western parts of the West Bengal region, whereas in Bangladesh about $71 \%$ of the potato area can be found in Rajshahi, the Northwestern parts of the country (Gatto et al. 2018). Potatoes are being cultivated in various cropping systems with maize, jute, or rice. In the case of ricefallow-rice systems, potatoes are ideally planted in November and harvested in early February when pest pressure is still low (Fig. 2). The short fallow period ideally requires either earlymaturing rice or potato varieties. However, in our study region generally longer maturing varieties are cultivated causing substantial yield penalties (Islam et al. 2014).

Double transplanting (DT) has been identified as a promising technique for rice-potato-rice cropping systems (Bardhan Roy et al. 2007). Originally, DT was applied in flood-prone areas to reduce the risk of rice submergence. From the nursery bed, rice tillers are first planted to medium or higher-level lands, in case the lower level main land is still flooded. A double transplanting to the main land is done after a month or so after the water receded (Azad and Hossain 2006). In the case of intensification, DT allows the cultivation of a 90-days potato to be followed by (DT) rice without

\footnotetext{
${ }^{1}$ See Bardhan Roy et al. (2007) for more benefits of DT.
}

incurring a yield penalty. ${ }^{1}$ We only refer to (DT) rice where appropriate because it does not fully comply with SI's idea of producing more with the same area of land.

For purpose of this study, we dinstiguish two intensification strategies. Rice systems in the Eastern IGP are intensified by (1) complementing or (2) substituting existing cropping systems. Complementing occurs when additional crops are added to existing systems, using the fallow period. In contrast, substitution of crops occurs when rice is replaced with another crop, such as jute or maize (Fig. 2). Whereas jute substitutes kharif rice, maize substitutes boro rice. The distinction is important because in this paper we are mostly interested in analyzing systems which complement traditional rice-based systems. However, other rice-based systems which also substitute one rice cycle are referred to in the analysis. Rice-fallow-rice systems will serve as a reference throughout this paper.

\section{Materials and Methods}

\section{Expert Opinions}

Expert opinions are used to gain first-hand local insights revolving around SI in our target area. In a simple mapping exercise, we created a problem/solution tree. In a first step, the major problem was identified on top of the tree. The group of experts comprised of breeders, extensionists, socio-economists, and were all employed in the public or private cereal/potato sector. They identified the following as the major problem: 'agriculture is not intense enough'. In the subsequent steps, we brainstormed to identify sub-problems and constraints to intensification. After this exercise, all problems were then 'turned' into solutions. The mapping exercise took place during a workshop on 'potato cropping systems in Asia' which the International Potato Center organized in Bangladesh from February 22-25, 2016. A total of 22 experts from various national and international institutes attended the workshop. ${ }^{2}$

In addition, we used expert opinions to gain a better understanding of the availability of early maturing potato varieties and to estimate potato adoption. This was important because official FAO data on land-use are only available at the national level and do not include adoption at the varietal level. Expert elicitation workshops in Bangladesh and West Bengal were used to estimate current varietal adoption rates of potatoes locally. The workshops in Bangladesh and West Bengal were attended by 24 and 16 experts working in the local potato value chain, respectively. Most of them were breeders, processors, extension agents, private and public officials, as well

\footnotetext{
${ }^{2}$ The workshop has a website where the problem/solution tree can be found. Additional information is also there, such as objectives and participant details. https://sites.google.com/a/cgxchange.org/workshop-in-nepal/home; accessed July 17, 2019).
} 
as farmers. The workshops followed standardized guidelines and methods to ensure consistency in data collection.

\section{Literature Review}

The literature review aims at providing a list of existing empirical and overview studies conducted on the intensification of rice systems in the study region. We used google scholar and did not discriminate against research without peer-review. This was a conscious decision because publications for rice-potato systems in our study region are scant. We collected, organized, and clustered the results for various cropping systems. The results of this exercise are summarized in Table 1A in the appendix. Most of the studies compare systems in terms of productivity (i.e., rice-yield-equivalent) and profitability (i.e., production costs, gross returns, net returns). Literature on social, food security, and environmental indicators are scant and system level comparisons are not possible. Thus, we did not list these in Table 1A. Most of the results concern Bangladesh. However, since both study areas are similar regarding agroecologies, we assume that in West Bengal results are same.

\section{Simulations}

A simulation exercise was carried out to estimate the economic benefits accrued by intensifying the rice-fallow-rice system in Bangladesh with early-maturing potato. Due to data constraints, the modeling part excludes West Bengal. The exercise was based on the economic surplus model approach (Alston et al. 1998) which simulates the market equilibrium in the demand and supply of a given commodity and can estimate the welfare changes when a productivity or demand shock occurs. Contrary to productivity shocks for a real commodity that can be represented with a parallel shift of the supply curve, the intensification of a cropping system with an additional crop presents several major challenges. First, the cropping system itself is not a real commodity, but a sequence of crops grown during a given period. Therefore, a 'market' cannot be strictly defined. Instead, the cropping system can be considered as a 'virtual' commodity, with a 'virtual' market. Even under this convention, however, any possible welfare benefits from intensification cannot be
Table 1 Potato area by varietal maturity and region in 2015

\begin{tabular}{lllll}
\hline & $\begin{array}{l}\text { Area } \\
\text { (in ha) }\end{array}$ & $\begin{array}{l}\text { Area } \\
\text { (in \%) }\end{array}$ & $\begin{array}{l}\text { Early } \\
\text { (in \%) }\end{array}$ & Medium (in \%) \\
\hline Bangladesh & 462,000 & 100 & 4 & 79 \\
Rajshahi & 329,637 & 71 & 0.3 & 75 \\
Dhaka & 70,522 & 15 & 1 & 90 \\
Khulna & 21,594 & 5 & 1 & 97 \\
Chittagong & 40,277 & 9 & & 82 \\
West Bengal & 411,219 & 100 & 11 & 62 \\
South & 206,125 & 50 & 15 & 67 \\
Plains & 82,450 & 20 & & 54 \\
West & 121,614 & 29 & 11 & 57 \\
Hills & 1031 & & & 100 \\
Total & 873,219 & & 7 & 71 \\
\hline
\end{tabular}

Early-maturing is between 75-89 days; medium maturing is between 90 119 days; for West Bengal and Plains 'Medium late' category not shown. Source: adapted from Gatto et al. (2018)

calculated based on changes of the assumed market equilibrium, simply because the new equilibrium corresponds to the market of a different 'virtual' commodity; that of a rice system intensified with potato. Moreover, intensification will affect all crops comprising the system thus, supply changes for both rice and potato should be modeled. However, the information identified in the literature is not sufficient to characterize the possible impact of intensification on yields and input requirements for the two crops individually/separately.

To overcome the above challenges, we did not compare the two systems directly inside an economic surplus model, but instead we estimated the yield gain that would be required for the non-intensified system to reach the net profit levels achieved by the intensified one. Therefore, we treated intensification as a productivity change occurring in the nonintensified system (system 1): we initially estimated a 'market price' $p_{1}$ for the initial system by dividing its average gross returns by its average RYE. The result of this calculation represents the economic value per ton of the system and provids the basis for simulating the equilibrium point in this 'virtual' market. We then estimated the necessary increase of the RYE in system 1 , denoted by $\Delta\left(R Y E_{1}\right)$ to achieve gross returns
Fig. 2 Selected cropping patterns in Eastern Indo-Gangetic Plains adapted from Biswas et al. (2006) and Islam et al. (2014)

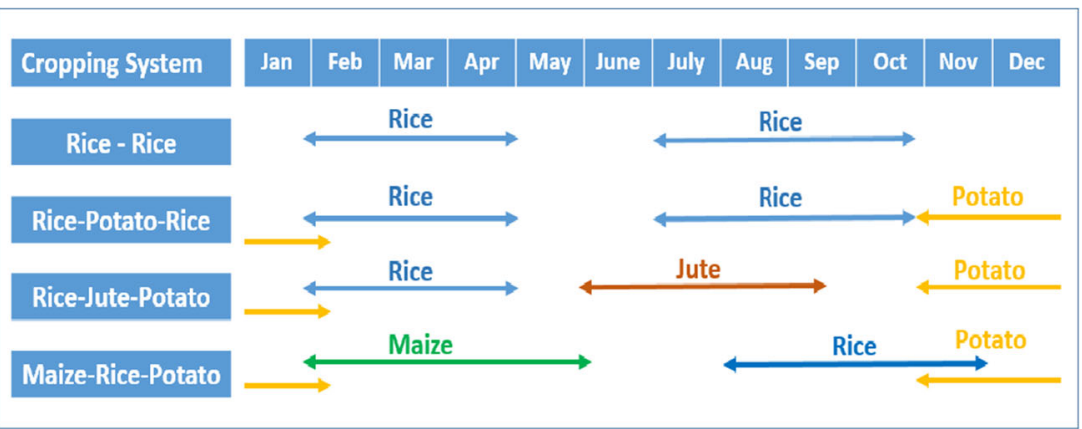


equal to those of the intensified system (denoted as system 2), given a 'market' price $p_{1}$ :

$$
\begin{aligned}
p_{1} & \times\left[R Y E_{1} \times\left(1+\Delta\left(R Y E_{1}\right)\right)\right] \\
& =\text { Gross returns }(\text { system } 2)
\end{aligned}
$$

This simplistic procedure allowed the use of the economic surplus model to simulate the assumed productivity change in the rice-fallow-rice system which can be represented by the supply shift $k_{t}$, specified by Alston et al. (1998) as:

$$
\mathrm{k}_{\mathrm{t}}=\left(\frac{\Delta\left(\mathrm{RYE}_{1}\right)[\%]}{\varepsilon_{\mathrm{s}}}\right)-\left(\frac{\Delta \mathrm{C}[\%]}{\left(1+\Delta\left(\mathrm{RYE}_{1}\right)[\%]\right)}\right) \times \mathrm{A}_{\mathrm{t}}
$$

where $\varepsilon_{s}$ is the price elasticity of supply, $\Delta C$ is the input cost change $\left(\Delta C=C_{2}-C_{1}\right)$, and $A_{t}$ is the intensification rate at year $t$ (the annual percentage of rice areas intensified with potato), which is given by the linear function:

$A_{t}=\left\{\begin{array}{cc}\alpha+\beta t & \text { for } t<t_{\max } \\ A_{\max } & \text { for } t \geq t_{\max }\end{array}\right.$

In the above equation, $A_{\max }$ is the maximum intensification rate, achieved $t_{\text {max }}$ years after the initial adoption, whereas $\alpha$ and $\beta$ are parameters.

Numerical values for all the parameters used in the modeling exercise were taken from the assessment of potato research priorities for the CGIAR Research Program on Roots, Tubers and Bananas (Hareau et al. 2014), which included the development of early-maturing potato varieties (technology named 'Agile potato') aiming exactly at the intensification of rice systems in Asia. Specifically, the elasticity parameters for demand and supply, the latter appearing in eq. (1), were 1.0 and 0.5 respectively. The maximum intensification rate, $A_{\max }$, in eq. (3) was set to $7 \%$ of all rice-fallow-rice areas in Bangladesh (i.e., 95,950 ha, out of 1.4 million ha) which is expected to occur in 10 years. In addition to a base run, the model was also solved parametrically for different values of the maximum intensification rate, ranging between $7 \%$ and $14 \%$, that is, between $\left[A_{\max }, 2 A_{\max }\right]$, with a step of 0.1 . In every run, the time in which maximum intensification occurred was assumed to extend by one year, so that 1.1Amax would occur in 11 years, 1.2Amax in 12 years and so forth. Although these constitute strong ad hoc assumptions, they reasonably capture the dynamics of the intensification process since the maximum rate is set proportional to the time required for it to occur. Invoking this assumption also highlights the need for more detailed information regarding intensification rates and the dynamics of the process. In each case, the Net Present Value (NPV) of the welfare benefits from intensification was calculated for a period of 20 years using a discount rate of $10 \%$. A dissemination cost of 50 US\$/ha was also assumed.

\section{Results and Discussion}

\section{Potential of Sustainable Intensification in Eastern IGP}

The expert elicitation reveals that about $7 \%$ (or $61,125 \mathrm{ha}$ ) of the total potato area in our study region is planted to earlymaturing varieties (i.e.,, Granola in Bangladesh; Kufri Pukhraj, K22, Kufri Chandramukhi in West Bengal) (Gatto et al. 2018) which are suitable for intensification in ricefallow-rice cropping systems. Earliness has been identified as relatively most important also in the context of climate change adaptation in India (Pradel et al. 2019). Medium bulking varieties which mature at best within 90 days cover $71 \%$ (or 619,985 ha) of the total potato area (Table 1).

Medium bulking potato varieties can also be used in intensified rice-fallow-rice systems but then in combination with an early maturing rice variety, such as BD56, BINA 7 or IT4904/ IR-36, preceding potato, or with double transplanting technique.

Irrespective of whether an early-maturing rice or potato variety is used, as mentioned earlier, about 6.2 million hectares suitable for intensification are left fallow. Among the various reasons for this, access to improved early-maturing varieties is an evident one.

\section{Effects of SI on Farming Outputs}

\section{Productivity and Profitability}

Probably the most important aspect of SI is the prospect of producing more food (on same area land and sustainably) while being profitable to incentivize farmers to intensify their systems. Regarding productivity, the literature review reveals that intensified rice systems are more than twice as productive than traditional rice-based systems. Whereas rice-fallow-rice systems have an average RYE of about 10.6 tha, all studied rice-potato systems return significantly higher RYEs (Fig. 3). Additionally, system productivity may be further increased by using early maturing rice varieties preceding potatoes. Currently, usually longer maturing rice varieties delay planting of potatoes in December causing yield penalties due to early harvest and late blight emergence (Islam et al. 2014). The same may hold true for early-maturing potato varieties. More research is warranted in this regard.

We further found significant differences among rice-potato systems. Especially, the yield of rice-potato-rice systems (19.64 t/ha) is significantly lower than the jute-potato-rice $(23.23 \mathrm{t} / \mathrm{ha})$ and rice-potato-maize cropping systems (23.25 t/ha). Here, it is worth noting that the systems follow a substitution strategy in which one of the two rice cycles is replaced, in addition to holding potatoes in the fallow.

Yields in the double transplanting cropping system are the highest (27.37 t/ha) among all examined systems and significantly different from rice-potato-rice systems. The DT of rice 


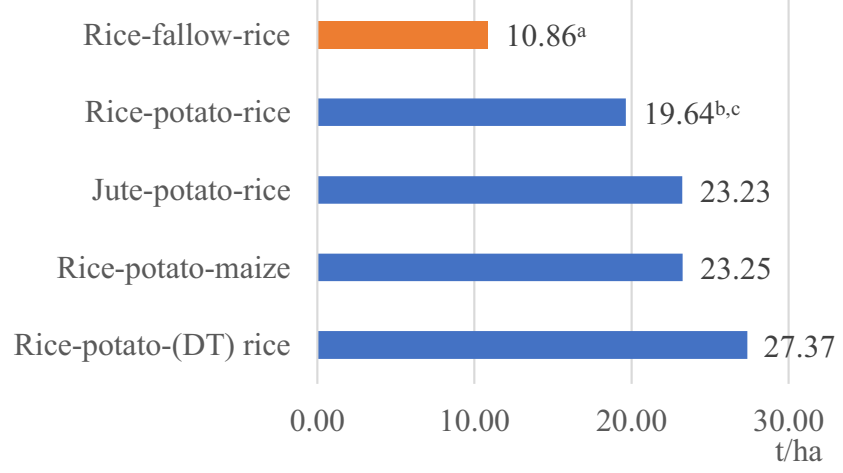

Fig. 3 Rice-Yield-Equivalent of potato-rice cropping systems. DT = Double Transplanted. Source: own calculations; based on t-test, ${ }^{\text {a }}$ significantly different from all other cropping systems at $p<0.00$ level; $\mathrm{b}$ significantly different from jute-potato-rice and rice-potato-maize at $p<0.1$ level; ${ }^{\mathrm{c}}$ significantly different from rice-potato-(DT) rice at $p<0.05$ level

following potatoes allow the rice to be harvested without a yield penalty (Bardhan Roy et al. 2007).

Regarding profitability, the literature review further showed that production costs of the traditional rice-fallow-rice systems averaged 1,626 US\$/ha and net returns averaged 327 US\$/ha (Table 2). In comparison, when farmers replace the fallow with potatoes, production costs jump to 2,396 US\$/ha, which is statistically significant. Obviously, an increased use of inputs, such as fertilizer, pesticides, labour, (clean) seed and irrigation, is required to intensify the system. Interestingly, fertilizer costs increase proportionally less compared to other inputs used.

In return, farmers can expect significantly higher profits, which more than triple, reaching 1,124 US\$/ha. Similar significantly different results are found for jute-potato-rice and rice-potatomaize cropping systems. Compared with rice-fallow-rice, expected profits are higher by $39 \%$ for rice-potato-rice, by $27 \%$ for jutepotato-rice, and by $19 \%$ for rice-potato-maize as the BCRs reveal (Table 2).

Productions costs for rice-potato-(DT) rice are not statistically different from other potato cropping systems, with the exception of rice-potato-maize, whose production costs are significantly higher. ${ }^{3}$ Table 2 also reveals significantly higher average net returns of rice-potato-(DT) rice compared with all other cropping systems. The large BCR of 2.19 underlines the economic superiority of the double transplanted system. This finding is relevant when comparing rice-potato-rice with the double transplanted version: at similar costs, double transplanting generates considerably higher profits. The found insignificant difference in costs may be due to few observations for DT cropping systems. However, the literature review revealed that DT required less inputs. For example, irrigation was reduced because of early harvest of DT rice in summer month; pesticide use was reduced due to harvesting both potatoes and rice earlier when pest pressure is

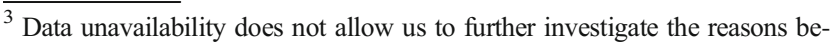
hind this.
}

relatively lower; labour demand and costs increases which may partly be offset because labour is needed most in off season where wages are lower.

Double transplanting returns higher profits because yield penalties caused by early harvest of potatoes or delayed planting of rice are minimized (Bardhan Roy et al. 2007; Islam et al. 2014; Arya et al. 2015). In addition, farmers can expect higher market prices for early harvesting potatoes and rice. Double transplanting may be the superior system, a constraint remains that it requires additional land to do the first transplanting. Though the additional land may be negligible, it does not fully comply with the core idea of sustainable intensification.

Demonstrating economic viability of the intensified cropping system is an important pre-condition for uptake of any technology and to incentivize farmers to produce more food. However, farmers might face various constraints which affect their adoption decision. For example, as rice is a staple in many Asian countries, inputand output markets are much more developed compared with those for potatoes. A risk-averse farmer thus continues producing rice for own consumption rather than engaging in un(der)developed potato markets. In addition, the analysis showed that much higher costs of production are associated with potato cultivation. Farmers may be financially constrained to pay for the additional inputs, particularly for (clean) seed, and labour. Higher labour costs, availability of hired and family labour may pose additional constraints, particularly in off-seasons. We discuss labour availability and opportunities for women in a following section.

Prices for potatoes are fluctuating at national and international markets. Since 2006, prices in India and Bangladesh have increased from some $130 \mathrm{US} \$$ /ton to about $180 \mathrm{US} \$$ /ton along an increasing potato production (FAOSTAT 2016). However, price volatility annually and during the past decade make potato production a risky endeavor which is especially the case for Bangladesh and less so for India (Hajong et al. 2014). Despite uncertain future potato prices, seasonal price volatility maybe be partly offset by an adequate cold storage infrastructure which would allow farmers to store production and sell when prices are higher (Fuglie et al. 1997). Currently, cold storage infrastructure is inadequate and cold storage fees are high, prompting farmers to sell their potatoes shortly after harvest (Hajong et al. 2014).

The figures discussed above were used for a simple economic surplus model exercise which reveals that intensifying a ricefallow-rice system with potato can produce economic benefits of 800 million US\$ over a 20-year period (Fig. 4). As previously explained, a basic assumption of the model simulations is that the intensidied area over the course of 20 years will be twice as high as the the rice-fallow-rice areas which are currently reported in Bangladesh. This means that the estimated economic benefits correspond to about 192,000 ha of land intensified. However, the graph may shift to the right (or left) depending on how demand (and prices) develop empirically. Note that these findings only hold for Bangladesh and are contingent on 
Table 2 Profitability of cropping systems

\begin{tabular}{|c|c|c|c|c|c|c|}
\hline Cropping system & $\mathrm{N}$ & Year & Production costs & Gross returns & Net returns ${ }^{\mathrm{m}}$ & $\begin{array}{l}\text { Benefit-Cost- } \\
\text { Ratio }\end{array}$ \\
\hline & & & (in US\$) & (in US\$) & (in US\$) & \\
\hline Rice-fallow-rice & 9 & 2010 & $1,626^{\mathrm{a}}$ & $1,954^{\mathrm{b}}$ & $327^{\mathrm{c}}$ & $1.23^{\mathrm{d}}$ \\
\hline Rice-potato-rice & 12 & 2008 & 2,396 & 3,520 & $1,124^{\mathrm{f}}$ & $1.62^{\mathrm{i}}$ \\
\hline Jute-potato-rice & 9 & 2010 & 2,665 & 3,881 & $1,216^{\mathrm{g}}$ & $1.50^{\mathrm{j}}$ \\
\hline Rice-potato-maize & 4 & 2011 & $2,891^{\mathrm{e}}$ & 4,100 & $923^{\mathrm{h}}$ & $1.42^{\mathrm{k}}$ \\
\hline Rice -potato-(DT) rice & 3 & 2004 & 1,929 & 4,310 & 2,314 & 2.19 \\
\hline
\end{tabular}

$D T=$ Double Transplanted

All figures are averages based on farmer field trials. Based on t-test, ${ }^{\mathrm{a}, \mathrm{b}, \mathrm{c}, \mathrm{d}}$ Significantly different at $p<0.00$ level compared with all other cropping systems; ${ }^{\text {ef, }, \mathrm{g}, \mathrm{h}, \mathrm{I}, \mathrm{j}, \mathrm{k}}$ Significantly different from Rice-potato-(DT) rice. Source: own calculations based on secondary data collected from literature review;

$\mathrm{m}$ include total value of produced crops (i.e. farmer decision to sell or consume takes place after)

the modelling assumptions. However, given the proximity of both regions, we assume similar findings for West Bengal.

\section{Increased Calorie Production}

Rice is one of the most important sources of energy in the study region. About $2 / 3$ of the daily per capita calorie demand is satisfied by rice consumption. Rahman and Islam (2013) found that daily rice consumption was about $1,700 \mathrm{cal} / \mathrm{capita}$ in Bangladesh in 2007-2008. In comparison, potato only contribute 100 cal to daily intake.

On the production side, potato yields widely exceed those of rice. Potatoes thus out-produce major rice crops in terms of per hectare calorie production (Scott 2002). Including potato in rice cropping systems may significantly contribute to an additional calorie production contributing to food security in the region.

Apart from increased calorie production, diversification of rice cropping systems largely increases the production of micronutrients which is necessary to combat hidden hunger, affecting children and women most (Graham et al. 2007). Potatoes are low in fat and rich in micronutrients, such as Vitamin C, B1,

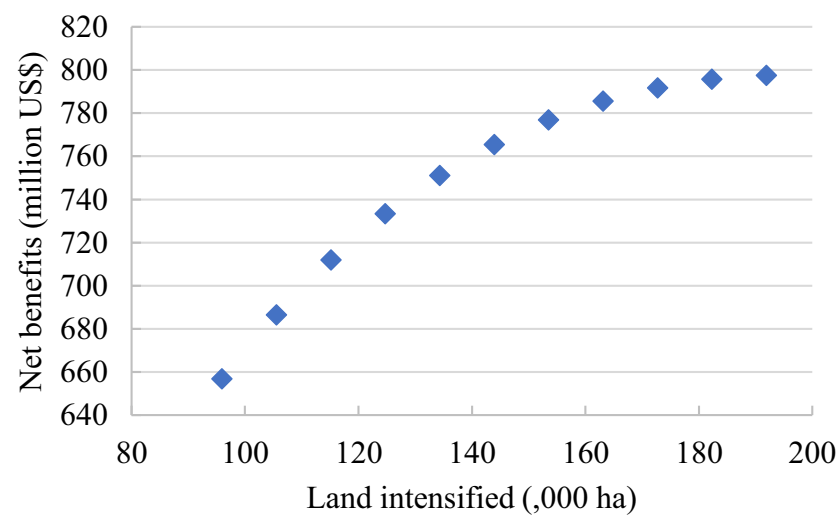

Fig. 4 Estimated welfare benefits from the intensification of rice systems with potato in Bangladesh. Each point corresponds to a model result for a different intensification rate, ranging from 95,950 ha to 191,900 ha of intensified land
B3, B6, and Iron. An increased potato consumption including skin contributes to the fight against hidden hunger (FAO 2009).

\section{Effects of SI on Input Use}

\section{Labour}

Demand for labour will inevitably increase when rice-systems are intensified. Generally, this may offer employment opportunities for rural areas, ideally contributing to rural economic development. However, the reality in our study region might be different. Despite expanding populations, rural out migration affects the supply of labour, which is particularly the case for the rural youth. At the same time, agricultural wages have been rising consistently, incurring additional costs on farming operations, especially in peak season (Himanshu and Kundu 2016).

Against this backdrop, rural households may rather use family labour. This, in turn, likely depends on the opportunity cost of family labour and other factors, such as the involvement in other low-productivity home production activities (i.e., child care, food preparation, etc.) which are favored by family members. For Bangladesh there is some evidence which suggests that, while agricultural productivity and rural wages increase, households increase the share of family labour to higher productivity activities instead of employing hired labour (Emran and Shilpi 2018). Examining if this is only the case for rice, or it may also be applicable for increasing agricultural productivity of the entire cropping system through intensification, is an important avenue of future research.

Timing of labour demand is crucial. In peak periods, labour demand and costs are very high. In contrast, in lean periods, such as the Monga period in Bangladesh, labour is readily available and costs are relatively low. Offering employment opportunities for rural people is important during this period (September-November) before rice is harvested because it imposes hardship on rural people in which crop incomes are low and food deprivation occasionally causes famines (Khandker 
2012; Islam et al. 2014). Intensifying rice-based systems with potatoes may offer additional employment opportunities during October and November. This may be achieved through shifting rice harvest to October and timely planting of potatoes. An early-maturing rice variety may add 45 labour days (1 labour day equals $8 \mathrm{~h}$ ) to the Monga period. In case of timely planting of potatoes in November, additional labour days may be created which, however, fall into the peak season where labour costs are generally higher. In addition, an early-maturing rice variety reduces the expected yield penalty from early harvest.

Regarding double transplanting rice, additional 14 labour days per hectare are needed compared with a non-DT scenario adding to the overall costs (Azad and Hossain 2006). In contrast, Bardhan Roy et al. (2007) found that labour costs do not vary much between the DT and non-DT scenario because additional labour is needed for weeding in the non-DT case. However, DT allows to shift the demand for labour to an earlier (first transplanting) and later (double transplanting) point of the rice season avoiding labour demand peaks. Apart from relieving pressure on the labour market, DT enables farming households to utilize their family labour for a longer period of time (Azad and Hossain 2006).

Unemployment rates for women are high in Bangladesh. Estimates indicate that in rural areas about 17 million women were unemployed in 2012 (Rahim 2015). Intensification could boost women's employment in the case of complementing rice systems. For potato cultivation in India, women's labour is required on 87 days per hectare (170 labour days for men) (Biswas et al. 2006). Another study further distinguishes labour demand by family and hired labour. Rahman (2000) found an overall small proportion of women's involvement in potato cultivation (13.8\%), of which $12.5 \%$ family labour directly contributes. Although women labour appears to have increased over the past decade, potato cultivation is still dominated by men and there seems to be more opportunities for female family than hired female labour.

Generally, sustainable intensification provides employment opportunities for men, women, youth, hired and family labour alike, and especially during periods of hardship. However, more research is warranted regarding the availability of labour in rural areas, especially during peak seasons, and thus making farming and related activities attractive for the youth and suitable for women. In doing so, research is needed on the opportunity (costs) of family labour to spend their time differently in low-productivity home production. Mechanization of agricultural practices, especially in relation to labour savings and women's involvement in agriculture (Sims and Kienzle 2015), may also be an interesting avenue of future research.

\section{Fertilizers and Pesticides}

In absolute terms, potato cultivation requires high fertilizer application usually at a rate of NPK $200-43-125 \mathrm{~kg} / \mathrm{ha}$, in relation to cereal crops such as rice (e.g. boro rice NPK is 100-22-42 kg/ha, kharif rice NPK 60-13-25 kg/ha) (Biswas et al. 2006). Obviously, complementing rice systems drastically increases the overall per hectare usage of fertilizers. However, on a per ton of rice/potato output basis, kharif rice requires about $35 \%$ more fertilization and boro rice even $167 \%$ more. $^{4}$ In addition, many farmers apply fertilizers by broadcasting techniques which are very inefficient making use of large amounts of fertilizer which can be very costly and damaging to the environment (Biswas et al. 2006).

Despite the increment in fertilizer usage, many experiments point to the positive residual effects of intensification on crops following potato. For instance, in rice and maize systems, only few additional fertilizer applications are needed for the crops succeeding potatoes (Ali et al. 2008; Arya et al. 2015). In case wheat and sunflower succeed potato, the $\mathrm{N}$ fertilizer requirements may be reduced by half which, however, are short-term effects ( $2-3$ years) with long-term residual effects remain unknown (Singh et al. 2007).

Additional pesticide use will be required in the intensified systems. However, in comparison with kharif rice, pesticide costs for potatoes are about $50 \%$ higher; in comparison with boro rice, the costs are similar (Biswas et al. 2006). For potato cultivation, fungicides will be needed especially later in the crop cycle to reduce late blight infestations which is more of an issue with raising temperatures. Early harvest, for instance achieved by using early-maturing varieties, reduces the disease pressure. In addition, the introduction of potatoes usually delays planting of boro rice by $15-25$ days. In a similar vein, rice will be more exposed to diseases and pests due to increasing temperatures. The overall greater demand for pesticides to control outbreaks and the related costs inevitably increase (Bardhan Roy et al. 2007), and so do the negative effects on the environment.

\section{Water Usage}

Kharif rice uses the least amount of irrigation, because of sufficient rainfall during the cropping cycle. Boro rice and potatoes generally depend on irrigation. On a per ton output basis, ${ }^{5}$ boro rice requires about $900 \%$ more water than potatoes (Biswas et al. 2006). Substituting rice for potato could thus reduce the pressure on water on basis of tonnage produced. Following a complementing strategy will require substantially more water. Traditionally, the water used in the winter season stems from rivers and canals, as well as irrigation tapping groundwaters which are charged during the summer monsoon rainfall. Irrigation is allowed for the cultivation of boro rice in

\footnotetext{
${ }^{4}$ These results are based on experimental productivity of 24 t/ha (potato) and $4 \mathrm{t} /$ ha (rice).

${ }^{5}$ These results are based on experimental productivity of 24 t/ha (potato) and $4 \mathrm{t} /$ ha (rice).
} 
the winter and about $90 \%$ of the Eastern IGP' agricultural land is irrigated (Balasubramanian et al. 2012).

In the intensified system, potatoes planted in November may still benefit from higher levels of soil moisture reducing irrigation requirements, whereas delayed planting of boro rice and potatoes results in higher water demand due to raising temperatures (Bardhan Roy et al. 1999; Bardhan Roy et al. 2007).

The potential for intensifying rice systems will largely depend on the availability of water, as Arya et al. (2015) point out at the example of DT. Intensification will pressure existing groundwater levels. However, the Bangladeshi government has started to discourage the cultivation of boro rice in Bangladesh's upland areas due to its high water requirements (Rabbani and Rahman 2015) underlining the potential for potato intensification.

\section{Effects of SI on Environmental Indicators}

Generally, more inputs are required for intensifying ricefallow-rice systems with potato. Increasing use of pesticides and chemical fertilizer, in turn, undoubtedly have negative implications for the environment and eco-systems (Liu et al. 2015). In addition, the (over) utilization of rainwater and irrigation may reduce soil fertility and water quality by leaching of nutrients which degrades groundwater quality (Govaerts and Vaghi 2012). Intensifying the cropping system also affects the intensity of tillage which, in turn, may reduce soil organic carbon levels (Jat et al. 2011).

Despite the overall negative environmental implications, intensified rice-potato systems may also be environmentally beneficial. For instance, Walia et al. (2010) find that potato intensification leads to higher levels of soil nitrogen, phosphorus and potash, only after 3 consecutive years of experimentation (Biswas et al. 2006). For other cropping patterns which include potato, similar positive effects on soil fertility have been observed whereas soil fertility indicators are reduced in rice systems (Singh and Lal 2011). However, a longer spell of 17 years of the same cropping pattern has been found to drastically lower soil fertility and to contribute to hard pan formation (Singh et al. 2007). Regarding organic carbon content, though it may be reduced considerably in rice cropping systems, potato intensification increases the content of organic matter in the soil (Biswas et al. 2006) or, at best, initial carbon values are kept (Walia et al. 2010). Generally, more research is needed to better understand the various environmental effects of intensification with potato.

However, the mere intensification of rice-based systems cannot be a solution in itself. To reduce environmental impacts, it is necessary to consider other farming practices to make intensification sustainable and, at the same time, produce more food on same area of land. Improved farming practices exist for all major inputs applied in intensified rice-potato-rice system which substantially reduce input usage while increasing or maintaining yields. First, through integrated pest management (IPM) pesticide applications can be reduced by about $30 \%$ while increasing yields by $40 \%$ on average (Pretty and Bharucha 2015). In the case of potato, evidence exists on the reduced production costs associated with IPM in Ecuador (Yaguana et al. 2016). The authors also pointed out that due to the knowledge intensity of IPM, adoption dissipates after some years. Second, improving fertilizer use efficiency may be achieved through increasing farmer knowledge of environment and fertilizer management $(\mathrm{Ma}$ et al. 2014), such as integrated nutrient management which has been proposed for cereal cropping systems in Indo-Gangetic Plains in India (Kakraliya et al. 2017). Third, water efficiency may be increased through dripping irrigation or, in the special case of potatoes, through partial root-zone drying (Yactayo et al. 2013). Finally, zero tillage can substantially reduce the negative effects on soil quality and prevent carbon release. This technique is expanding in the lowlands of Vietnam in rice-potato-rice systems, in which fields are drained with furrow after rice harvest, followed by planting of seed tubers with fertilizer application in the soil around the tubers, and using the leftover straws to cover the beds (FAO 2016). In addition to reducing negative environmental implications, this technique is associated with considerable labour savings. In particular, a reduction in heavy physical work reduces the dependency on adult men and offers opportunities for women and elder people to work in agriculture.

\section{Conclusion}

Sustainable intensification has recently been promoted as a strategy to produce more food for a growing population, whilst reducing inputs used and minimize negative environmental effects. Tradeoffs, however, are inevitable and context-specific evidences which integrate socio-economic, food security, and environmental factors are scant. In this research we developed and applied a sustainability indicators framework for intensified rice-fallow-rice cropping systems with potatoes. We use the example of the Eastern Indo-Gangetic Plains where an estimated 6.2 million hectares of land suitable for intensification with potatoes and other crops are left fallow.

Sustainable intensification holds potential in our study area, while at the same time, farming households are required to make tradeoffs and are affected by exogenous factors. An important sustainability factor is that the improved system is economically viable creating incentives for farmers to intensify existing cropping systems. Despite the demonstrated higher profitability of SI with potatoes and the higher expected yields and food produced compared to traditional rice-based systems, it seems to be an insufficient requirement for its adoption. For instance, farming households must trade off other (incomegenerating) activities or lower productivity activities. Demands for other inputs, such as fertilizer, pesticides and (most important) water will increase and availability and prices 
are outside the control of farming households. As a result, production costs will increase but farmers may have financial constraints and limited access to credit. In addition, non-traditional crops such as potatoes are subject to higher price volatility and more unstable demand which increases the risk for farmers. A lacking cold store infrastructure may only partly reduce the risks. Furthermore, the increased demand and use for inputs will inevitably affect the environment, mostly negative. Although various strategies and techniques exist to increase input efficiency, as proposed in this study, farmers rarely apply them due mainly to lack of knowledge.

These factors will largely determine the success of SI; the estimated national economic welfare benefits and the large potential (fallow) area to be sustainably intensified are, however, relevant prerequisites. Therefore, providing opportunities to farming households to produce more with the same area of land needs to go hand-in-hand with a range of institutional innovations (Schut et al. 2016), creation of demand and the development of a potato value chain potentially in combination with the private sector.

We conclude that more empirical research on tradeoffs of sustainable intensification for rice-based systems with potatoes is needed. This research intends to contribute to the a marginal but increasing body of literature and, at the same time, points to the necessity to analyze complex phenomena, such as sustainable intensification, in a more integrated fashion. For this study in particular, empirical context-specific evidence is required on the various tradeoffs and constraints-end- or exogenous of nature- which farming households are facing, while considering the entire cropping systems rather than single crops. And in doing so, the proposed framework may be applied to various other cropping systems and contexts.

Finally, food productivity on existing land will need to increase in a sustainable way to guarantee a food secure world for generations to come.

Acknowledgements This work was undertaken as part of the CGIAR Research Programs on Policies, Institutions, and Markets (PIM). Funding support for this study was provided by the CGIAR Research Program on Policies, Institutions, and Markets (PIM) and the CGIAR Research Program on Roots, Tubers and Bananas (RTB).

\section{Appendix}

Open Access This article is licensed under a Creative Commons Attribution 4.0 International License, which permits use, sharing, adaptation, distribution and reproduction in any medium or format, as long as you give appropriate credit to the original author(s) and the

Table 1A Literature review metadata

\begin{tabular}{|c|c|c|c|c|}
\hline Variable & $\begin{array}{l}\text { Cropping } \\
\text { System }\end{array}$ & $\begin{array}{l}\text { Obs. in } \\
\text { Bangladesh }\end{array}$ & $\begin{array}{l}\text { Obs. in West } \\
\text { Bengal }\end{array}$ & Source \\
\hline \multirow{7}{*}{$\begin{array}{l}\text { Productivity: } \\
\quad \text { Rice-Yield-Equivalent }\end{array}$} & Rice-fallow-rice & 8 & 1 & Biswas et al. (2006); Rabbani and Rahman (2015) \\
\hline & Jute-potato-rice & 8 & 1 & Biswas et al. (2006); Rabbani and Rahman (2015) \\
\hline & Rice-potato-maize & 5 & 0 & Biswas et al. (2006); Rabbani and Rahman (2015) \\
\hline & Rice-potato-rice & 10 & 1 & Biswas et al. (2006); Rabbani and Rahman (2015) \\
\hline & $\begin{array}{l}\text { Rice-potato-rice } \\
\text { (DT) }\end{array}$ & 2 & 0 & Kadian et al. (2008) \\
\hline & Potato-rice (DT) & 0 & 1 & Arya et al. (2015) \\
\hline & Potato-rice & 0 & 1 & Arya et al. (2015) \\
\hline \multirow{4}{*}{$\begin{array}{l}\text { Profitability: Production Costs / } \\
\text { Gross Return / Net Return } \\
\text { Arya et al. (2015); Rabbani and } \\
\text { Rahman (2015) }\end{array}$} & Rice-fallow-rice & 8 & 5 & Biswas et al. (2006); Bardhan Roy et al. (2007) \\
\hline & & & & \\
\hline & Jute-potato-rice & 8 & 1 & Biswas et al. (2006); Rabbani and Rahman (2015) \\
\hline & Rice-potato-rice & 10 & 2 & Biswas et al. (2006); Bardhan Roy et al. (2007) \\
\hline \multicolumn{5}{|c|}{$\begin{array}{l}\text { Kadian et al. (2008); Rabbani and } \\
\quad \text { Rahman (2015) }\end{array}$} \\
\hline & Rice-potato-maize & 5 & 0 & Rabbani and Rahman (2015) \\
\hline & $\begin{array}{l}\text { Rice-potato-rice } \\
\text { (DT) }\end{array}$ & 2 & 1 & Bardhan Roy et al. (2007); Kadian et al. (2008) \\
\hline $\begin{array}{l}\text { Daily per capita calorie } \\
\text { consumption }\end{array}$ & 1 & 0 & $\begin{array}{l}\text { Rahman and } \\
\text { Islam } \\
\text { (2013) }\end{array}$ & \\
\hline Micronutrients & & & & FAO (2009) \\
\hline Labour & $\begin{array}{l}\text { potato and rice } \\
\text { systems }\end{array}$ & 5 & 1 & $\begin{array}{l}\text { Bardhan Roy et al. (2007); Biswas et al. (2006); Islam et al. (2014); } \\
\text { Jabbar and Faruque (1978); Rahim (2015); Rahman (2000) }\end{array}$ \\
\hline Fertilizer & potato & 1 & 1 & Biswas et al. (2006); Bardhan Roy et al. (1999); (Singh et al. (2007) \\
\hline Pesticides & potato & 0 & 1 & Bardhan Roy et al. (2007) \\
\hline Water & potato & 1 & 2 & Biswas et al. (2006); Bardhan Roy et al. (2007) \\
\hline
\end{tabular}


source, provide a link to the Creative Commons licence, and indicate if changes were made. The images or other third party material in this article are included in the article's Creative Commons licence, unless indicated otherwise in a credit line to the material. If material is not included in the article's Creative Commons licence and your intended use is not permitted by statutory regulation or exceeds the permitted use, you will need to obtain permission directly from the copyright holder. To view a copy of this licence, visit http://creativecommons.org/licenses/by/4.0/.

\section{References}

Aggarwal, P.K., P.K. Joshi, J.S. Ingram, and R.K. Gupta. 2004. Adapting food systems of the indo-Gangetic plains to global environmental change: Key information needs to improve policy formulation. Environmental Science \& Policy. 7 (6): 487-498.

Ali, M. Y., S. R. Waddington, D. P. Hodson, J. Timsina and J. Dixon. 2008. Maize-rice cropping systems in Bangladesh: Status and research opportunities. CIMMYT.

Alston, J., G. Norton, and P. Pardey. 1998. Science under scarcity: Principles and practice for agricultural research evaluation and priority setting. Wallingford, Cambridge: CABI.

Arya, S., M. Ahmed, S.K. Bardhan Roy, M.S. Kadian, and R. Quiroz. 2015. Sustainable intensification of potato in rice based system for increased productivity and income of resource poor farmers in West Bengal, India. International Journal of Tropical Agriculture. (India). ISSN 0254-8755 33 (2): 203-208.

Azad, M. A. S. and M. Hossain. 2006. Double transplanting: Economic assessment of an indigenous Technology for Submergence Avoidance in the flood-prone Rice environment in Bangladesh. In: International Association of Agricultural Economists Conference, Gold Coast, Australia (pp. 12-18).

Balasubramanian, V., T. K. Adhya and J. K. Ladha. 2012. Enhancing ecoefficiency in the intensive rice-based systems of the indo-Gangetic Plains. In eco-efficiency: From vision to reality, ed. Clair H. Hershey. Cali, Colombia: International Center for Tropical Agriculture (CIAT).

Bardhan Roy, S. K., T. S. Walker, V. S. Khatana, N. K. Saha, V. S. Verma, M. S. Kadian, A. J. Haverkort and W. Bowen. 1999. Intensification of potatoes in rice-based cropping systems: A rapid rural appraisal in West Bengal. Working Paper No. 1999-1 (CIP).

Bardhan Roy, S. K., N. K. Saha, M. S. Kadian, R. Quiroz and S. Ilangantilege. 2007. Improving the livelihood of farmers by intensifying the rice-potato-rice system through double-transplanting of rice in West Bengal, India. International Potato Center.

Biswas, B., D.C. Ghosh, M.K. Dasgupta, N. Trivedi, J. Timsina, and A. Dobermann. 2006. Integrated assessment of cropping systems in the eastern indo-Gangetic plain. Field Crops Research 99 (1): 35-47.

Emran, S., and F. Shilpi. 2018. Agricultural productivity, hired labour, wages, and poverty: Evidence from Bangladesh. World Development. 109: 470-482.

FAO. 2009. International Year of the Potato: new Light on a Hidden Treasure. http://www.fao.org/potato-2008/en/events/book.html, accessed August 29, 2017.

FAO. 2015. The State of Food Insecurity in the World 2015. www.fao. org/3/a-i4646e.pdf, accessed August 29, 2017.

FAO. 2016. Save and Grow in Practice: maize, rice, wheat. http://www. fao.org/publications/save-and-grow/maize-rice-wheat/en/, accessed February 21, 2018

FAOSTAT. 2016. http://www.fao.org/faostat/en/\#home, accessed February 21, 2018.

Fuglie, K.O., V. S. Khatana, S. G. Ilangantileke, J. Singh, D. Kumar, G. J. Scott. 1997. Economics of potato storage in northern India.
International potato center, social science department. Working paper no.1997-5. ISSN 0256-8748.

Gatto, M., G. Hareau, W. Pradel, V. Suarez, J. Qin. 2018. Release and adoption of improved potato varieties in southeast and South Asia. International potato center (CIP) Lima, Peru. ISBN 978-92-9060501-0. 42p. Social sciences working paper no. 2018-2.

Garnett, T., M.C. Appleby, A. Balmford, I.J. Bateman, T.G. Benton, P. Bloomer, B. Burlingame, M. Dawkins, L. Dolan, D. Fraser, M. Herrero, I. Hoffmann, P. Smith, P.K. Thornton, C. Toulmin, S.J. Vermeulen, and H.C.J. Godfray. 2013. Sustainable intensification in agriculture: Premises and policies. Science. 341 (6141): 33-34.

Gerland, P., A.E. Raftery, H. Ševčíková, N. Li, D. Gu, T. Spoorenberg, L. Alkema, B.K. Fosdick, J. Chunn, N. Lalic, and G. Bay. 2014. World population stabilization unlikely this century. Science. 346 (6206): 234-237.

Godfray, H.C.J., and T. Garnett. 2014. Food security and sustainable intensification. Phil. Trans. R. Soc. B. 369 (1639): 20120273.

Govaerts, B. and F. Vaghi. 2012. Compendium of deliverables of the conservation agriculture course 2010. Vi. 82 pages. Mexico, DF (Mexico). CIMMYT. http://repository.cimmyt.org/handle/10883/ 1366. Accessed August 29, 2017.

Graham, R.D., R.M. Welch, D.A. Saunders, I. Ortiz-Monasterio, H.E. Bouis, M. Bonierbale, S. De Haan, G. Burgos, G. Thiele, R. Liria, and C.A. Meisner. 2007. Nutritious subsistence food systems. Advances in agronomy. 92: 1-74.

Hajong, P., M.D. Moniruzzaman, I.A. Mia, and M. Rahman. 2014. Storage system of potato in Bangladesh. Universal Journal of Agricultural Research. 2 (1): 11-17.

Hareau, G., U. Kleinwechter, W. Pradel, V. Suarez, J. Okello, V. Surjit. 2014. Strategic assessment of research priorities for potato. CGIAR research program on roots, tubers and bananas (RTB) working paper no. 2014-8. Available online at: www.rtb.cgiar.org

Himanshu, and S. Kundu. 2016. Rural wages in India: Recent trends and determinants. Indian Journal of Labour Economics. 59: 217.

Indian Council of Agricultural Research. 2018. http://www.icar.org.in/ files/state-specific/chapter/125.htm, accessed February 21, 2018.

Islam, M.K., M.S. Mahfuz, S. Ghosh, A.S.M.Y. Ali, and M.Z. Hasnat. 2014. Improvement of potato based cropping patterns by inclusion of short duration Mungbean and T. Aman rice in Monga prone areas of Rangpur. International Journal of Agricultural Research, Innovation and Technology. 4 (2): 35-40.

Jabbar, M.A., and A.K.M. Faruque. 1978. Labour requirements for production of major crops in Bangladesh. Bangladesh Journal of Agricultural Economics. 1 (1).

Jat, M.L., Y.S. Saharawat, and Rajgupta. 2011. Conservation agriculture in cereal systems of South Asia: Nutrient management perspectives. Karnataka Journal of Agricultural Sciences. 24 (1): 100-105.

Kadian, M. S., A. H. Khan, M. Hossain, M. Ibrahim, R. Quiroz, S. G. Ilangantileke, V. Mares, M. M. M. Rahman and T. K. Dey. 2008. Double transplanting technology of boro rice in the rice-potato-rice system for enhanced productivity and reduced poverty in Bangladesh. Conference Proceedings. 168-168.

Kakraliya, S.K., R.D. Jat, S. Kumar, K.K. Choudhary, J. Prakash, and L.K. Singh. 2017. Integrated nutrient Management for Improving, fertilizer use efficiency, soil biodiversity and productivity of wheat in irrigated Rice wheat cropping system in indo-Gangatic Plains of India. International Journal of Current Microbiology and Applied Sciences. 6 (3): 152-163.

Khandker, S.R. 2012. Seasonality of income and poverty in Bangladesh. Journal of Development Economics. 97: 244-256.

Knox, J., T. Hess, A. Daccache, and T. Wheeler. 2012. Climate change impacts on crop productivity in Africa and South Asia. Environmental Research Letters. 7 (3): 034032.

Kumar, S.N., P.M. Govindakrishnan, D.N. Swarooparani, C. Nitin, J. Surabhi, and P.K. Aggarwal. 2015. Assessment of impact of climate 
change on potato and potential adaptation gains in the indo-Gangetic Plains of India. International Journal of Plant Production. 9 (1).

Liu, Y., X. Pan, and J. Li. 2015. A 1961-2010 record of fertilizer use, pesticide application and cereal yields: A review. Agronomy for Sustainable Development. 35: 83.

Ma, L., S. Feng, P. Reidsma, F. Qu, and N. Heerink. 2014. Identifying entry points to improve fertilizer use efficiency in Taihu Basin. China. Land Use Policy. 37: 52-59.

Masters, W.A., A.A. Djurfeldt, C. De Haan, P. Hazell, T. Jayne, M. Jirström, and T. Reardon. 2013. Urbanization and farm size in Asia and Africa: Implications for food security and agricultural research. Global Food Security. 2 (3): 156-165.

Ndiritu, S.W., M. Kassie, and B. Shiferaw. 2014. Are there systematic gender differences in the adoption of sustainable agricultural intensification practices? Evidence from Kenya. Food Policy 49 (1): 117-127.

Pradel, W., M. Gatto, G. Hareau, S. K. Pandey and V, Bhardway. 2019. Adoption of potato varieties and their role for climate change adaptation in India. Climate Risk Management. 23: 114-123.

Pretty, J., and Z.P. Bharucha. 2015. Integrated Pest Management for Sustainable Intensification of agriculture in Asia and Africa. Insects. 6: 152-182.

Rabbani, G. and A. Rahman. 2015. Indentifying and recommending vegetable based cropping patterns for project targeted areas and development of manual for crop production. MIMEO.

Rahim, M. A. 2015. Role of vegetables for solving micronutrient deficiency (hidden hunger) in Bangladesh. In: Proceedings of the Regional Symposium on Sustaining Small-Scale Vegetable Production and Marketing Systems for Food and Nutrition Security (SEAVEG2014), 25-27 February 2014, Bangkok, Thailand (pp. 84-88). AVRDC-the world vegetable center.

Rahman, S. 2000. Women's employment in Bangladesh agriculture: Composition, determinants and scope. Journal of Rural Studies. 16 (4): 497-507.

Rahman, K.M.M., and M.S. Islam. 2013. Nutritional status and food security of farm households under different land use patterns in Bangladesh. Bangladesh Journal of Nutrition. 24: 49-64.

Schut, M., P. van Asten, C. Okafor, C. Hicintuka, S. Mapatano, N.L. Nabahungu, D. Kagabo, P. Muchunguzi, E. Njukwe, P.M. Dontsop-Nguezet, and M. Sartas. 2016. Sustainable intensification of agricultural systems in the Central African highlands: The need for institutional innovation. Agricultural Systems 145: 165-176.
Scott, G.J. 2002. Maps, models, and muddles: World trends and patterns in potatoes revisited. Potato Research. 45 (1): 45-77.

Sims, B., and J. Kienzle. 2015. Mechanization of conservation agriculture for smallholders: Issues and options for sustainable intensification. Environments. 2: 139-166.

Singh, S.K., and S.S. Lal. 2011. Integrated nutrient management in potato based cropping systems in South Bihar alluvial plains. Potato Journal (India). 38 (2): 162-169.

Singh, J. P., V. K. Dua, M. Kumar, P. M. Govindakrishnan and S. S. Lal. 2007. Resource Management in Potato Based Cropping Systems. Central potato research institute, Shimla, India. Technical bulletin no. 83.

Smith, A., S. Snapp, R. Chikowo, P. Thorne, M. Bekunda, and J. Glover. 2017. Measuring sustainable intensification in smallholder agroecosystems: A review. Global Food Security. 12: 127-138.

Theriault, V., M. Smale, and H. Haider. 2017. How does gender affect sustainable intensification of cereal production in the west African Sahel? Evidence from Burkina Faso. World Development. 92: 177-191.

Tilman, D., C. Balzer, J. Hill, and B.J. Befort. 2011. Global food demand and the sustainable intensification of agriculture. Proceedings of the National Academy of Sciences of the United States of America. 108 (50): 20260-20264.

Walia, S.S., M.S. Gill, and S.S. Dhaliwal. 2010. Production potential and economics of different cropping systems and their impact on soil health. Indian Journal of Ecology. 37 (1): 23-26.

Wheeler, T., and J. Von Braun. 2013. Climate change impacts on global food security. Science. 341 (6145): 508-513.

World Bank. 2012. Poverty \& Equity Data for India and Bangladesh. http://povertydata.worldbank.org/poverty/country/IND, accessed August 29, 2017.

Yactayo, W., D.A. Ramirez, R. Guiterrez, V. Mares, A. Posadas, and R. Quiroz. 2013. Effect of partial root-zone drying irrigation timing on potato tuber yield and water use efficiency. Agricultural Water Management. 123: 65-70.

Yaguana, V.C., J. Alwang, G. Norton, and V. Barrera. 2016. Does IPM have staying power? Revisiting a potato-producing area years after formal training Ended. Journal of Agricultural Economics. 67 (2): 308-323.

Zurek, M., P. Keenlyside, and K. Brandt. 2015. Intensifying agricultural production sustainably: A framework for analysis and decision support. In Amsterdam, the Netherlands: International food policy research institute (IFPRI). Climate: Focus http://ebrary.ifpri.org/cdm/ ref/collection/p15738coll2/id/130125. 